\title{
The adaptation of domestic ruminants to environmental constraints under extensive conditions
}

\author{
Kevin D. Sinclair ${ }^{\mathrm{a} *}$, Jacques Agabriel ${ }^{\mathrm{b}}$ \\ ${ }^{a}$ Scottish Agricultural College, Craibstone Estate, Bucksburn, Aberdeen, AB21 9YA, UK \\ ${ }^{\mathrm{b}}$ Laboratoire adaptation des herbivore aux milieux, Inra, Theix, \\ 63122 Saint-Genès-Champanelle, France
}

(Received 11 May 1998; accepted 14 September 1998)

\begin{abstract}
The dietary energy requirements for maintenance of suckling ruminants typically account for more than $75 \%$ of the animals total annual energy requirements and are influenced by animal size and productive potential. Consequently, it is the maintenance requirement of a ruminant animal in relation to feed intake that will primarily determine the success with which it adapts to its nutritional environment. In the case of the female ruminant, it is energy intake above maintenance that influences her ability to grow and conceive; and to partition nutrients towards the developing conceptus and suckling young. Emerging evidence suggests that the ability of the female ruminant to do the latter may have implications for the lifetime performance and fertility of her offspring. The legacy of undernutrition in utero for the performance of future generations, however, remains to be determined. Within a nutritional environment, factors such as ambience and herbage availability and quality can be manipulated at key stages of the animals reproductive life and annual breeding cycle so as to alleviate some of the difficulties of genotype selection. Ways and means by which this can be achieved are discussed. (C) Elsevier/Inra
\end{abstract}

\section{extensification / ruminants / genotype / nutrition / reproduction}

Résumé - L'adaptation des ruminants domestiques aux contraintes environnementales en conditions d'extensification. Les besoins d'entretien des ruminants menés en système allaitant correspondent à plus de $75 \%$ des besoins énergétiques totaux avec des variations selon la taille de l'animal et son potentiel de production. De ce fait ce sont ses besoins d'entretien (et sa capacité d'ingestion) qui vont en premier lieu déterminer la réussite de son adaptation à son milieu nutritionnel. Dans le cas de la femelle cela va d'abord influer sur son aptitude à croître et à concevoir ; puis si nécessaire, à orienter les nutriments vers le développement du conceptus et l'allaitement du jeune. Des résultats récents semblent indiquer que la capacité de la femelle à l'allaitement peut avoir des effets sur la periormance et la fertilité de sa progéniture. En revanche, un effet rémanent de la sous-nutri-

\footnotetext{
* Correspondence and reprints

Tel.: (44) 1224711063 ; fax: (44) 1224711 292; e-mail: k.sinclair@ab.sac.ac.uk
} 
tion in utero sur les performances des générations suivantes reste encore à déterminer. Pour un même environnement nutritionnel, plusieurs facteurs tels que la qualité et/ou la disponibilité des fourrages peuvent être modulés à des périodes clés du cycle de production et de la vie reproductive pour aplanir certaines difficultés inhérentes au choix des races. Les voies et moyens d'y arriver sont discutés. (1) Elsevier/Inra

\section{extensification / ruminants / génotype / nutrition / reproduction}

\section{INTRODUCTION}

Under most extensive systems of ruminant livestock production breeding animals spend their lives in the thermal and nutritional environment in which they are born and this determines the degree to which they achieve their productive potential. Environmental conditions within the European continent range from being hot and arid to being cold and wet, and at each of these two extremes forage availability will be limiting. The effects of low levels of nutrition on animal growth and development can be experienced from an early age. Indeed, through its effects on the growth and development of foetal tissue and organs, nutrition can influence adult performance. These early programming effects will continue to influence animal performance through puberty and adolescence, and into adulthood. The success with which a ruminant adapts to its nutritional environment will depend to a large extent on the requirements for maintenance and productive purposes of the biological type in question relative to the quantity, quality and seasonal distribution of available nutrients. In the case of the female ruminant this success will determine her reproductive competence and hence biological efficiency.

This paper is concerned with examining how different biological types of ruminant adapt to their nutritional environment during early life; and the consequences that this might have on animal performance in later life. After identifying the nutritional requirements of ruminants under extensive conditions, and how these are influenced by genotype, season and herbage quality, this paper will consider the factors that influence herbage intake, and hence the ability of ruminants to meet their requirements. The final section of the paper considers the consequences of nutritional environment on animal performance.

\section{ANIMAL REQUIREMENTS UNDER EXTENSIVE CONDITIONS}

\subsection{Effect of biological type}

The proportion of the annual dietary energy requirements of suckling ruminants required for maintenance is typically around $75 \%$ of the total for a beef cow $[24,61]$ and for single and twin-bearing ewes it is 80 and $73 \%$ respectively. Much effort has, therefore, been devoted to quantifying the maintenance requirements of such animals. A positive relationship is known to exist between the genetic potential for production (growth and/or milk production) and maintenance requirements with commonly accepted values for the metabolisable energy (ME) requirements for maintenance $\left(\mathrm{ME}_{\mathrm{m}}\right)$ in thermoneutral conditions of between $0.40-0.55 \mathrm{MJ} \mathrm{ME} \cdot \mathrm{kg}^{-1} \mathrm{Wt}^{0.75}$ for dry beef cows; $0.50-0.65 \mathrm{MJ} \mathrm{ME} \cdot \mathrm{kg}^{-1} \mathrm{Wt}^{0.75}$ for lactating beef cows; and up to $0.77 \mathrm{MJ} \mathrm{ME} \cdot \mathrm{kg}^{-1}$ $\mathrm{Wt}^{0.75}$ for lactating dairy cows [86]. Commonly accepted values for $M E_{m}$ in sheep vary from 0.4 to $0.8 \mathrm{MJ} \cdot \mathrm{kg}^{-1} \mathrm{Wt} 0.75$. Such ranges are related to differences in body composition and the size and metabolic rate of the visceral organs [24, 77]. In cattle, $\mathrm{ME}_{\mathrm{m}}$ allowances may need to be increased by $10-50 \%$ to meet the requirements of locomotion in difficult terrain and by slightly 
higher proportions for sheep in similar circumstances [6].

\subsection{Effect of season and climate}

Seasonal variations in requirements for energy for general maintenance purposes and the achievement of live weight stability in cattle are considered to be mainly due to seasonal variation in body composition [48] rather than seasonal variation in thermoneutral maintenance energy requirements [9]. General energy expenditure is also closely associated with animal activity, which tends to be greater in the summer than in the winter, at least in deer [73].

Our understanding of the thermal requirements of ruminants in temperate climates is sufficiently detailed to allow us to accurately predict the effects of climate on the performance of dairy cows, beef cows and growing calves using mathematical models [16]. One model [15] predicts sensible heat loss from the parameters air temperature, wind speed, net radiation and rainfall, and has been used to quantify the benefits of different types of shelter, including housing, shelter belts and woodlands. For example, the model predicts that in cold $\left(5^{\circ} \mathrm{C}\right)$, wet (5 $\mathrm{mm}$ rain per day) and windy (wind velocity of $9 \mathrm{~m} / \mathrm{s}$ ) conditions a non-pregnant, lactating cow would require $104 \mathrm{MJ} \mathrm{ME} /$ day to maintain constant body weight and that this value would not be reduced by housing. In contrast, the food energy requirements of a non-pregnant, non-lactating cow would increase proportionately by 0.31 (72 versus $55 \mathrm{MJ} \mathrm{ME} / \mathrm{day}$ ) if it was kept outside rather than housed in the same conditions. The increase in metabolic heat production associated with the increased level of ME intake necessary to support lactation enables lactating animals to be more tolerant to adverse climatic conditions. Thus, animals may remain productive in such circumstances, but this will depend on the provision of adequate levels of food energy during the period of adversity. This conclusion is support- ed by recent evidence from Sweden, where growing cattle fed outside during the winter achieved similar growth rates ( $533 \mathrm{~g} / \mathrm{day}$ ) to their contemporaries that were fed indoors $(553 \mathrm{~g} /$ day) on the same diet [65].

\subsection{Effect of forage quality}

In extensive conditions most, if not all, the requirements for energy and other nutrients must be supplied by naturally occurring grass or conserved forage. Therefore, the requirements of the ruminant animal will be influenced by factors that influence herbage availability and quality in addition to those associated with animal species and breed type.

It is recognised that the efficiency of utilisation of dietary energy for maintenance, growth and lactation depends on diet quality (metabolisability; ME/GE; [6, 42]). Metabolisable energy is utilised less efficiently in low quality diets and so forage availability must be adjusted accordingly. Until recently, however, a fixed value $(0.133)$ for the efficiency of utilisation of $\mathrm{ME}$ for conceptus growth $\left(\mathrm{k}_{\mathrm{c}}\right)$ has been used, so that the metabolisable energy requirements of pregnant ruminants, particularly those carrying two or three foetuses, have been poorly estimated. Although not perhaps significant in terms of the animals total annual energy requirements, inadequate provision of metabolisable energy during gestation can have serious consequences for the viability and performance of the dam and offspring (see section 4.3). There is now evidence from sheep studies that $k_{c}$ is positively correlated with the energy density (M/D) of the diet $[38,66]$. In order to illustrate its significance, this finding is applied to cattle to predict the effect of diet quality on the requirements for ME during gestation. A $550 \mathrm{~kg}$ non-lactating, single-bearing beef cow (genetic potential mature weight of $750 \mathrm{~kg}$ ), which experiences zero maternal (i.e., excluding the conceptus) live-weight change, fed a diet with an M/D of $7.4 \mathrm{MJ} \cdot \mathrm{kg}^{-1} \mathrm{DM}$ 
(0.6 UFL $\cdot \mathrm{kg}^{-1} \mathrm{DM}$; late cut hay) would require $33 \%$ more $\mathrm{ME}$ than an equivalent cow fed a diet with an M/D of $12.9 \mathrm{MJ} \cdot \mathrm{kg}^{-1}$ DM (1.1 UFL $\left.\cdot \mathrm{kg}^{-1} \mathrm{DM}\right)$ in pregnancy to week 40 of gestation. It is clear, therefore, that the quality of forage, i.e., its metabolisability, has a large effect on the efficiency of energy utilisation for all the functions of ruminant animals and, hence, on their energy requirements.

\section{HERBAGE INTAKE UNDER EXTENSIVE CONDITIONS}

Under extensive grazing conditions intake is primarily limited by herbage availability and digestibility. Ruminants can compensate for low herbage availability, to a certain extent, by increasing the time spent grazing, but such activity has a cost. For example, cattle in the study of Holloway et al. [36] required about three times the amount of forage dry matter per $\mathrm{kg}$ live weight in order to achieve similar growth rates to those animals managed under intensive grazing conditions. Animals cannot compensate, however, for low herbage digestibility which affects both the energy available for use by the animal per $\mathrm{kg}$ DM intake and the intake of herbage DM. For cattle fed hay based diets, it has been predicted that every $1 \%$ decrease in the organic matter digestibility reduces intake by $33 \mathrm{~g} / 100 \mathrm{~kg}$ live weight [63].

For a given ruminant species, the animal related factors known to influence voluntary food intake (VFI) include genotype, size, age, body-condition score, physiological state and milk production $[26,43]$. The VFI of dairy females is known to be $10 \%$ higher than that of beef females of the same weight [5]. Among beef breeds Limousins have a relatively low intake capacity [29] which is similar to that of the Belgian Blue [32]. VFI calculated from several trials where diets were based on forages was shown to be allometrically related to live weight $($ coefficient $=0.9 ;[5,78])$, and to increase more quickly than their maintenance requirements expressed on a metabolic live weight basis. Thus, for animals differing in size, the largest may have an advantage in ad libitum feeding systems.

In the breeding cow, voluntary food intake is minimal just before parturition then increases rapidly to reach a maximum during the second month of lactation. Primiparous cows, however, have lower VFIs than adult cows (by $8 \%$ to $12 \%$ after adjustments are made for differences in size and milk production), but such differences are not so obvious in ewes. A strong relationship exists between VFI and milk production in high performing ruminants [22], and milk yield is often used as a predictor of intake in dairy cows and ewes $[11,23]$. This relationship is not so strong, however, among low producing ruminants [41].

\section{ANIMAL PERFORMANCE UNDER EXTENSIVE CONDITIONS}

\subsection{Attainment of mature body size and body composition}

Working with four beef cow genotypes that differed in terms of their potential mature size and milk production, Sinclair et al. [74] demonstrated that young, growing cows adjust their weight, body composition and milk yield to that which can be supported by the prevailing level of annual energy intake. Morris et al. [54] also reported that young cows ( 1 to 5 years of age) were lighter (by $9 \%$ ) than others of the same genotype when managed on the least favourable of three locations. However, permanent stunting in growth is unlikely to have occurred in animals in either study; rather these animals would have attained a steady-state body weight, since Taylor et al. [76] observed that all but the most severely food restricted heifers in their study resumed growth when realimented after 5 to 7 years of age and reached live weights approaching those of non feed restricted heifers. Little is known 
about the body composition of such animals, but maintenance efficiency was not significantly affected in that study. In studies where the nutritional environment during early life has failed to influence mature size (e.g., [79]), cows were exposed to bulls continuously and culling for reproductive failure was not practised. Therefore, these animals were able to gain weight and conceive at some later point.

\subsection{Seasonal changes in body composition and milk yield}

There are recognisable and quantifiable effects of season on changes in body composition [64], growth rate [4] and milk yield [46] among the different ruminant species. Growth rates, for example, are greater under long days than under short days for both lambs $[27,28]$ and calves $[4,55]$, and milk yields are also known to vary seasonally, with the highest yields occurring during the long days of summer [25]. Such effects arise from a complex interaction between food availability and quality, VFI [51], basal metabolic rate $[10]$ and nutrient partitioning.

Important differences between genotype and sex in the ability to respond to seasonal cues are known to exist both in cattle and sheep. For example, sheep genotypes selected for hill conditions at northern latitudes tend to exhibit greater seasonal patterns in VFI and, to a lesser extent, maintenance metabolic rate than genotypes recognised as being less seasonal in their reproductive behaviour and managed at lower altitudes [40]. At zero weight change mature non-pregnant and non-lactating beef cows lose body protein during the summer while gaining body fat, which is later mobilised during the winter and spring while body protein is being accreted [49]. Similar observations have been made in sheep [7]. Ball et al. [7] however, observed important differences between the two sexes. The seasonal oscillation in fat and protein weight was not only greater for rams than for ewes in that study but was also out of phase by 3.5 months. This phase shift was also observed by Laurenz et al. [49] between the two genotypes of cow in their study. Angus cows accreted body protein, on average, 3 months later than Simmental cows, during the spring. However, although the biological significance of these observations is apparent, the practical significance is not. More work is required to determine if the differences observed between genotypes in the studies cited above confer any selection advantage for extensive conditions.

\subsection{Early performance and later achievement}

\subsubsection{Attainment of puberty}

The optimal age of first calving in order to maximise lifetime performance and profit margins for most dairy and beef cows is considered to be around 24 months $[35,50]$. Lifetime productivity of ewes can also be increased by introducing them to the breeding flock as pubertal lambs in the first breeding season [21]. The achievement of such production targets is dependent on the onset of puberty which varies considerably between genotypes [53] and is influenced by pre-pubertal plane of nutrition [2], diet composition [68], and season $[2,69]$.

In cattle, Bos indicus genotypes tend to be older, heavier and taller at the onset of puberty than Bos taurus genotypes. Martin et al. [53] reported significant genetic variation among Bos taurus genotypes both within and between breeds for age at puberty. Breeds selected for dual purpose characteristics (e.g., Brown Swiss and Simmental) reach puberty earlier than breeds selected purely for growth and carcass characteristics (e.g., Charolais, Limousin and Hereford). In general, between beef breeds fast growing and late maturing breeds reach puberty later than slow growing and early maturing breeds. The overall heritability for onset of puberty among beef cattle, however, 
is high (at around 0.4); and age at puberty tends to be lower among crossbreds than among pure-breds.

Studies investigating the effects of nutrition on the attainment of puberty have been largely confined to those concerned with feeding level, growth rate and body weight and composition. In general, animals that are fed high planes of nutrition and grow rapidly during early life attain puberty earlier and at heavier weights than animals that are not fed so well. Both energy and protein restriction delayed the onset of puberty in ewe lambs in the study of Boulanouar et al. [13], but these authors concluded that weight gain was probably more important than type of dietary restriction in determining age at puberty. However, considerable variation in age, size and body composition at puberty exist both within and between breeds of cattle and sheep $[67,70]$.

In practice nutritional effects are confounded by season of birth in ways which make the results of many experiments difficult to interpret. Autumn born calves reach puberty earlier than spring born calves, but they tend to exhibit a bimodal pattern in the onset of puberty [69]. Heifers born during the early autumn period, particularly those with a genetic propensity to attain puberty at early ages, will do so during the following summer, whereas those born during the late autumn and early winter period, and have the genetic propensity to attain puberty at older ages, often do not attain puberty until the following spring. Melatonin receptors have been identified in foetal tissues as early as day 30 of gestation in both sheep [33] and deer [81], and may be instrumental in mediating the prenatal photoperiodic effects on postnatal reproductive maturation reported in these two species by Helliwell et al. [34] and Adam et al. [1]. The importance of such effects under ambient light is uncertain however, since they may be modified by post-natal photoperiodic changes.

\subsubsection{Milk yield potential}

The development of optimum feeding strategies for the management of replacement heifers and ewe lambs is complicated by the fact that the high planes of nutrition that favour the onset of puberty during the rearing period have a negative effect on mammary development and subsequent milk yields $[70,71]$. The relevance of this problem under extensive systems and indeed in single-suckled calf production systems, where the emphasis is on the total weight of calf weaned per cow kept in the herd rather than on the milk produced, has been questioned [44]. Although the growth rate and weaning weight of calves were reduced when heifers gained more than $0.55 \mathrm{~kg}$ per day from 2 to 8 months of age, the early attainment of puberty and improved fertility meant that, over a three year period, the total weight of weaned calf produced was greater for these animals.

\subsubsection{Reproductive potential}

The early attainment of puberty allows young ruminants to experience at least two to three oestrous cycles before mating, thus ensuring high levels of fertility to first service [17], and a high proportion of heifers delivering offspring within two years and ewe lambs within one year of birth. Low planes of nutrition during foetal and early post-natal life, however, in addition to delaying the onset of puberty and conception, can have longer term repercussions which extend late into adult life to influence the reproductive performance of the animal [31]. Recently, Borwick et al. [12] presented evidence that maternal undernutrition during the first nine weeks of pregnancy in sheep can delay the normal process of oocyte degradation and postpone the arrest of ovarian meiotic activity in female foetuses at day 62 of gestation, with possible consequences for oocyte number and reproductive performance in adult life. The effects of undernutrition during foetal and early 
post-natal life maybe confounded by plane of nutrition during adult life to further reduce fertility [30].

\subsubsection{Compensatory growth}

A characteristic feature of extensive systems of livestock production is the seasonal pattern of herbage availability and the associated seasonal pattern of live-weight change. For unweaned young stock, such seasonal shifts in nutrient intake and growth are buffered, to some extent, by the consumption of milk from the dam. The effectiveness of this buffer, however, is limited by the milk producing capability of the dam. In single suckled calf production systems, milk yields are known to vary between breeds and to be influenced by such factors as parity and plane of nutrition, resulting in small $(8$ to $12 \%)$ but significant differences in calf performance from birth to weaning $[60,74]$. Provided nutrient intake and calf growth rates are not unduly compromised during the first 4 months of life [58], most production systems will provide ample opportunity for compensatory growth in later life.

Compensatory growth is normally expressed over a relatively short period of time (typically 4 to 8 weeks on spring pasture), and arises as a consequence of increased VFI [39], reduced maintenance energy requirements [45] and increased efficiency of energy and protein utilisation [18]. Early body-weight gains following restriction comprise increased proportions of protein and water and a reduced proportion of fat, which is then followed by a period in which gains consist of an increased proportion of fat, such that eventually, body weight and composition of restricted animals returns to that of non-restricted animals [83]. The precise timing of these events and the composition of live-weight change both during and after compensation will, however, be dependent on genotype (early versus late maturing), sex and stage of maturity; and could be influenced by seasonal factors (section 4.2.) in ways which currently have not been fully investigated. What is known, however, is that compensatory growth in weaned suckled calves can be supported by a wide range of vegetation types [82].

Knowledge of the timing and extent of compensatory growth in peri-pubertal female ruminants can be used to overcome problems of impaired mammary growth and development (section 4.3.2.) which result as a consequence of rapidly growing ruminants striving to attain puberty at an early age (section 4.3.1) in order to maximise subsequent reproductive potential (section 4.3.3; $[19,59,85])$.

\subsection{Reproductive performance}

\subsubsection{Genotype $\times$ environment interactions}

Due to the competing demands of maintenance, pregnancy, lactation and maternal growth, heifers calving for the first time at between 2 to 3 years of age frequently have longer calving intervals over their first two parities than mature cows [52]. When young heifers are introduced to very poor nutritional environments, the resultant delays in onset of puberty and age at first calving are frequently carried into late adulthood [80]. Important interactions between the nutritional environment and genotype are likely to occur in such circumstances. Large and/or milky genotypes have the greatest requirements and so, consequently, may become thinner and less fertile than small and relatively less milky genotypes [54]. The literature in this area, however, is inconclusive. Working exclusively with mature cows, Nugent et al. [57] observed that low levels of annual energy intake (equivalent to average daily intakes of $650 \mathrm{~kJ} \mathrm{ME} \cdot \mathrm{kg}^{-1} \mathrm{Wt}^{0.75}$ ) had less of a detrimental effect on the interval from calving to first ovulation for relatively large and milky genotypes (Gelbvieh and Simmental) than for relatively large and non-milky genotypes (Limousin and Cha- 
rolais). Sinclair et al. [75] offered 705 and $820 \mathrm{~kJ}$ ME$\cdot \mathrm{day}^{-1} \cdot \mathrm{kg}^{-1} \mathrm{Wt}^{0.75}(0.06$ and 0.07 $\mathrm{UFL} \cdot$ day $^{-1} \cdot \mathrm{kg}^{-1} \mathrm{Wt}^{0.75}$ ) to young first and second parity cows in their study, and observed that the large and non-milky genotype (Charolais) had longer intervals from calving to first ovulation and lower conception rates compared to the large and milky genotype (Simmental). Other studies conducted in France $[20,37,62]$ lend support to the idea that important genotype $\times$ nutritional environment interactions exist particularly among primiparous cows. It would seem that genotypes selected for large mature size and very lean growth characteristics maybe less fertile and more sensitive to fluctuations in dietary energy intake than those selected for 'dual purpose' characteristics.

\subsubsection{Control of ovulation}

In domestic ruminants nutritional status is known to influence both the ability of the animal to ovulate and the number of ovulations. In cattle the effects of nutritional status are largely constrained to the achievement of ovulation, whereas, in sheep nutritional status can also influence the number of ovulations.

It can take several months for an ovarian follicle that leaves the primordial pool to reach the point whereby it undergoes terminal maturation and ovulates. Consequently, dietary restriction 6 months prior to ovulation in sheep has been shown to influence ovulation rate [56]. Long term effects of nutrition on the reproductive axis can also operate by altering body tissue reserves (mainly lipid) during the peri-ovulatorary period, so influencing the general availability and equilibrium of metabolic fuels during this time. Body lipid reserves are highly correlated with ovulation rate in a number of species but there has been much debate in the literature as to whether or not body fat has any direct role in regulating ovulation [14]. Interest in the role of body fat in controlling ovulation was rekindled recently with the possible role of leptin, that is secreted from adipose tissue during lipogenesis, in regulating gonadotrophin secretion and gonadal activity [8].

Short term improvements in nutritional status can be very effective in improving ovulation rate in sheep, particularly those that are in relatively poor body condition as a consequence of being managed under extensive systems of production. Nottle et al. [56] observed a significant increase in ovulation rate in those ewes whose nutrition had been restricted 6 months prior to ovulation when their diet was supplemented with lupin grain (a legume high in digestible energy and protein). Adams et al. [3] hypothesised that the acute effects of nutrition may act to disrupt the tight feedback mechanisms that control ovulation rate so giving a rapid response. In practice, the ability of animals managed under extensive conditions to respond in such a manner will be dependent on the provision of good quality grass or supplementary feed during this key stage of the animals annual reproductive cycle.

\subsubsection{Post-partum anoestrus}

There are well established relationships for beef cows between the effects of preand post-partum nutrition, the interval from calving to first ovulation and the resumption of oestrous cycles of regular length [72]. Although pre- and post-partum nutrition are known to interact with one another to determine the interval from calving to first ovulation [84], pre-partum nutrition is generally considered to be more important than postpartum nutrition in this regard, particularly in primiparous cows. In heifers the negative effects of low energy intakes during the pre-partum period cannot be completely abolished by very high levels of dietary energy during the early post-partum period [47]. Working with first and second parity cows, Sinclair et al. [75] demonstrated that the interval from calving to first ovulation increased with live-weight loss during the first month post partum only in thin cows 
that were mobilising relatively large quantities of lean body tissue.

\section{CONCLUSIONS}

The process by which a ruminant animal adapts to its nutritional environment begins very early in life, prior to fertilisation and during the period of gametogenesis. The success with which a given species adapts to its nutritional environment will depend on the requirements for maintenance and growth of the genotype in question relative to that nutritional environment. This will influence body composition, and in the case of the breeding female, the ability to conceive and to partition nutrients towards the developing conceptus and suckling young. Certain genotypes are more sensitive to photoperiodic effects on VFI, nutrient partitioning and reproduction than others, and there is evidence that such effects may have their origin during early foetal life. Hence, in an era when agricultural production systems are becoming more extensive, judicious genotype selection for the more marginal ruminant livestock producing areas of Europe will be essential.

\section{REFERENCES}

11] Adam C.L., Kyle C.E., Young P., Influence of prenatal photoperiod on postnatal reproductive development in male red deer (Cervus elaphus), J. Reprod. Fertil. 100 (1994) 607-611.

[2] Adam Clare L., Robinson J.J., The role of nutrition and photoperiod in the timing of puberty, Proc. Nutr. Soc. 53 (1994) 89-102.

[3] Adams N.R., Briegel J.R., Sanders M.R., Blackberry M.A., Martin G.B., Level of nutrition modulates the dynamics of oestradiol feedback on plasma FSH in ovariectomized ewes, Anim. Reprod. Sci. 47 (1997) 59-70.

[4] Aharoni Y., Brosh A., Holzer Z., Photoperiodic effect on live-weight gain on bull calves, Anim. Sci. 65 (1997) 165-171.

[5] Agabriel J., D'hour P., Petit M., Influence de l'âge et de la race sur la capacité d'ingestion des femelles bovines, Reprod. Nutr. Dev. 7 (1987) 21-22.
16] Agricultural Research Council, The nutrient requirements of ruminant livestock, Commonwealth Agricultural Bureaux, Slough, 1980.

17| Ball A.J., Thompson J.M., Pleasants A.B., Seasonal changes in body composition of growing Merino sheep, Livestock Prod. Sci. 46 (1996) 173-180.

18] Barash I.A., Cheung C.C., Weigle D.S., Ren H., Kabigting E.B., Kuijper J.L., Clifton D.K., Steiner R.A., Leptin is a metabolic signal to the reproductive system, Endocrinology 137 (1996) 3144-3147.

19] Birkelo C.P., Johnson D.E., Phetteplace H.P., Maintenance requirements of beef cattle as affected by season on different planes of nutrition, J. Anim. Sci. 69 (1991) 1214-1222.

[10] Blaxter K.L., Boyne A.W., Fasting and maintenance metabolism of sheep, J. Agricult. Sci. 99 (1982) 611-620.

III Bocquier F., Guitard J.P., Vacaresse C., Van Quackebeke E., Delmas G., Guillouet Ph., Lagriffoul G., Morin E., Arrantz J.M., Estimation de la capacité d'ingestion et des phénomènes de substitution fourrage/concentré chez les brebis Lacaune conduites en lots, Compilation des données obtenues sur des rations à base d'ensilage, Renc. Rech. Ruminants 4 (1997) 75-78.

[12] Borwick S.C., Rhind S.M., McMillen S.R., Racey P.A., Effect of undernutrition of ewes from the time of mating on fetal ovarian development in mid gestation, Reprod. Fertil. Dev. 9 (1997) $1-10$.

|13| Boulanouar B., Ahmed M., Klopfenstein T., Brink D., Kinder J., Dietary protein or energy restriction influences age and weight at puberty in ewe lambs, Anim. Reprod. Sci.40 (1995) 229-238.

[14] Bronson F.H., Manning J.M., The energetic regulation of ovulation: a realistic role for body fat, Biol. Reprod. 44 (1991) 945-950.

[15] Bruce J.M., Modelling the climatic energy demand on suckler cows, Anim. Prod. 30 (1980) 449 (abstr.).

[16] Bruce J.M., Broadbent P.J., New techniques in modelling cattle production systems, in: Philips C.I.C. (Ed.), New Techniques In Cattle Production, Butterworths, London, 1989 , pp. 180-205.

[17] Byerley D.J., Staigmiller R.B., Berardinelli J.G., Short R.E., Pregnancy rates of beef heifers bred either on pubertal or third estrus, J. Anim. Sci. 65 (1987) 645-652.

[18] Carstens G.E., Johnson D.E., Ellenberger M.A., Tatum J.D., Physical and chemical components of the empty body during compensatory growth in beef steers, J. Anim. Sci. 69 (1991) 3251-3264. 
[19] Choi Y.J., Han K., Woo J.H., Lee H.J., Jang K., Myung K.H., Kim S., Compensatory growth in dairy heifers: the effect of a compensatory growth pattern on growth rate and lactation performance, J. Dairy Sci. 80 (1997) 519-524.

[20] Ducrot C., Gröhn Y.T., Humblot P., Bugnard F., Sulpice P., Gilbert R.O., Postpartum anestrus in French beef cattle: an epidemiological study, Theriogenology 42 (1994) 753-764.

[21] Dýrmundsson Ó.R., Advancement of puberty in male and female sheep, in: Fayez I., Marai M., Owen J.B. (Eds.), New Techniques in Sheep Production, Butterworths, London, 1987, pp. $65-76$.

[22] Faverdin P., Hoden A., Coulon J.B., Recommandations alimentaires pour les vaches laitières, Bull. Techn. C.R.V.Z. Theix 70 (1987) 133-152.

[23] Faverdin P., Richou B., Peyraud J.L., Influence d'infusions digestives d'acides gras volatils ou de glucose sur l'ingestion chez les vaches laitières en lactation ou taries, Ann. Zootech. 41 (1992) 93.

[24] Ferrell C.L., Jenkins T.C., Cow type and the nutritional environment: nutritional aspects, J. Anim. Sci. 61 (1985) 725-741.

[25] Forbes J.M., Effects of lighting pattern on growth, lactation and food intake of sheep, cattle and deer, Livestock Prod. Sci. 9 (1982) 361-374.

[26] Forbes J.M., in: Milligan L.P., Grovum W.L., Dobson A. (Eds.), Control of digestion and metabolism in ruminants, Prentice-Hall, Englewood Cliffs, NJ, 1986, pp. 420-435.

[27] Forbes J.M., El Shahat A.A., Jones R.. Duncan J.G.S., Boaz T.G., The effect of daylength on the growth of lambs, Anim. Prod. 29 (1979) 33-42.

[28] Francis S.M., Veenvliet B.A., Stuart S.K., Littlejohn R.P., Suttie J.M., The effect of photoperiod on plasma hormone concentrations in wether lambs with genetic differences in body composition, Anim. Sci. 65 (1997) 441-450.

[29] Geay Y., Production de taurillons Limousins 13,16 et 19 mois. Bull Tech. CRZV Theix 48 (1982) 21-26.

[30] Gunn R.G., The influence of nutrition on the reproductive performance of ewes, in: Sheep production, Haresign W. (Ed.), Butterworths, London, 1983, pp. 99-212.

[31] Gunn R.G., Sim D.A., Hunter A., Effects of nutrition in utero and in early life on the subsequent lifetime reproductive performance of Scottish Blackface ewes in two management systems, Anim. Sci. 60 (1995) 223-230.

[32] Hanset R., Michaux C., Stasse A., Relationships between growth rate, carcass composition, feed intake, feed conversion and income for four biological types of cattle, Génét. Sel. Evol. 19 (1987) 225-248.
[33] Helliwell R.J.A., Williams L.M., The development of melatonin-binding sites in the ovine fetus, J. Endocrinol. 142 (1994) 475-484.

[34] Helliwell R.J.A., Wallace J.M., Aitken R.P., Racey P.A., Robinson J.J., The effect of prenatal photoperiodic history on the postnatal endocrine status of female lambs, Anim. Reprod. Sci. 47 (1997) 303-314

[35] Hoffman P.C., Funk D.A., Applied dynamics of dairy replacement growth and management, J. Dairy Sci. 79 (1992) 2024-2031.

[36] Holloway J.W., Butts W.T., McCurley J.R., Beaver E.E., Peeler H.L., Backus W.L., Breed $x$ nutritional environment interactions for intake and digestibility of forage grazed by lactating beef females, J. Anim. Sci. 61 (1985) 1345-1353.

[37] Humblot P., Grimard B., Ribon O., Khireddine B., Dervishi V., Thibier M., Sources of variation of post-partum cyclicity, ovulation and pregnancy rates in primiparous Charolais cows treated with norgestomet implants and PMSG, Theriogenology 46 (1996) 1085-1096.

[38] Hutchings N.J., Estimating the metabolizable energy requirement for pregnancy in sheep, Anim. Sci. 64 (1997) 463-467.

[39] Iason G.R., Mantecon A.R., Milne J.A., Sim D.A., Smith A.D.M., White I.R., The effect of pattern of food supply on performance, compensatory growth and carcass composition of Beulah and Welsh Mountain lambs, Anim. Prod. 54 (1992) 235-241.

[40] Iason G.R., Sim D.A., Foreman E., Fenn P. Elston D.A., Seasonal variation of voluntary food intake and metabolic rate in three contrasting breeds of sheep, Anim. Prod. 58 (1994) $38 \mathrm{I}-387$

[41] Ingrand S., Agabriel J., Typology of the evolution of intake by Charolais cows around calving, Anim. Sci. 65 (1997) 361-371.

[42] Inra, Alimentation des ruminants, in: Jarrige R. (Ed.), Inra Publication, Route de Saint-Cyr, Versailles, 1978.

[43] Inra, Alimentation des bovins ovins, caprins, in: Jarrige R. (Ed.), Inra Publication, Route de Saint-Cyr, Versailles, 1988.

[44] Johnsson I.D., Obst J.M., The effects of level of nutrition before and after 8 months of age on subsequent milk and calf production of beef heifers over three lactations, Anim. Prod. 38 (1984) 57-68.

[45] Kabbali A., Johnson W.L., Johnson D.W., Goodrich R.D., Allen C.E., Effects of compensatory growth on some body component weights and on carcass and noncarcass composition of growth lambs, J. Anim. Sci. 70 (1992) 2852-2858.

[46] Kashiwamura F., Furumura K., Iketaki T., Shinde Y., Aotani H., Suda T., Sato F., Relationship between photoperiod and seasonality of milk production in dairy cattle, Anim. Feed Sci. Technol. 62 (1991) 1156-1158. 
[47] Lalman D.L., Keisler D.H., Williams J.E., Scholljegerdes E.J., Mallett D.M., Influence of postpartum weight and body condition change on duration of anestrus by undernourished suckled beef heifers, J. Anim. Sci. 75 (1997) 2003-2008.

[48] Laurenz J.C., Byers F.M., Schelling G.T., Greene L.W., Effects of season on the maintenance requirements of mature beef cows, J. Anim. Sci. 69 (1991) 2168-2176.

[49] Laurenz J.C., Byers F.M., Schelling G.T., Greene L.W., Periodic changes in body composition and in priorities for tissue storage and retrieval in mature beef cows, J. Anim. Sci. 70 (1992) 1950-1956.

[50] Lesmeister J.L., Burfening P.J., Blackwell R.L., Date of first calving in beef cows and subsequent calf production, J. Anim. Sci. 36 (1973) $1-8$.

[51] Louden A.S., Photoperiod and the regulation of annual and circannual cycles of food intake, Proc. Nutr. Soc. 53 (1994) 495-507.

[52] Lowman B.G., Feeding in relation to suckler cow management and fertility, Vet. Rec. 117 (1985) 80-85.

[53] Martin L.C., Brinks J.S., Bourdon R.M., Cundiff L.V., Genetic effects on beef heifer puberty and subsequent reproduction, J. Anim. Sci. 70 (1992) 4006-4017.

[54] Morris C.A., Baker R.L., Hickey S.M., Johnson D.L., Cullen N.G., Wilson J.A., Evidence of genotype by environment interaction for reproductive and maternal traits in beef cattle, Anim. Prod. 56 (1993) 69-83.

[55] Mossberg I., Jönsson H., The influence of day length and temperature on food intake and growth rate of bulls given concentrate or grass silage ad libitum in two housing systems, Anim. Sci. 62 (1996) 133-240.

[56] Nottle M.B., Kleemann D.O., Seamark R.F., Effect of previous undernutrition on the ovulation rate of Merino ewes supplemented with lupin grain, Anim. Reprod. Sci. 49 (1997) 29-36.

[57] Nugent III R.A., Jenkins T.G., Roberts A.J., Klindt J., Relationship of post-partum interval in mature beef cows with nutritional environment, biological type and serum IGF-1 concentrations, Anim. Prod. 56, 193-200.

[58] O'Donovan P.B., Compensatory gain in cattle and sheep, Nutr. Abstr. Rev. Series B. 54 (1984) $389-410$.

[59] Park C.S., Choi Y.J., Erickson G.M., Marx G.D., Effect of compensatory growth on regulation of growth and lactation: response of dairy heifers to a stair-step growth pattern, J. Anim. Sci. 64 (1987) 1751

|60| Petit M., Liénard G., Performance characteristics and efficiencies of various types of beef cows in French production systems, Proc. 3rd World Congress on Sheep and Beef Cattle Breeding,
19-23 June 1988, Paris. Vol. 2, Inra Publ., Paris, 1988, pp. 25-51.

[61] Petit M., Jarrige R., Russel A.J.F., Wright I.A., Feeding and nutrition of the suckler cow, in: Beranger C. (Ed.), Beef Cattle Production (World Animal Science) Vol. C5, Elsevier, 1993, pp. 191-207.

[62] Petit M., Agabriel J., État corporel des vaches allaitantes : signification, utilisation pratique et relations avec la reproduction, in: The role of specialized beef breeds in extensive husbandry systems of suckler cows, Proc. Scientific Day of the 28th World Charolais Congress, EAAP Publication No. 72, 1994, pp. 7-18.

|631 Petit M., Garel J.P., D’Hour P., Agabriel J., The use of forages by the beef cow herd, IV Symposium International sur la Nutrition des Herbivores, Clermont-Ferrand, Septembre 1995 , Recent Developments in the Nutrition of Herbivores, Inra Editions, Paris, 1995, pp. 473-496.

[64] Phillips C.J.C., Johnson P.N., Arab T.M., The effect of supplementary light during winter on the growth, body composition and behaviour of steers and heifers, Anim. Sci. 65 (1997) 173-181.

[65] Redbo I., Mossberg I., Ehrlemark A, Ståhl-Högberg M.. Keeping growing cattle outside during winter: behaviour, production and climatic demand, Anim. Sci. 62 (1996) 35-41.

[66] Robinson J.J., McDonald I., Fraser C., Gordon J.G., Studies on reproduction in prolific ewes. 6 . The efficiency of energy utilisation for conceptus growth, J. Agricult. Sci. 94 (1980) 331-338.

[67] Robinson J.J., Nutrition in the reproduction of farm animals, Nutr. Res. Rev. 3 (1990) 253-276.

[68] Robinson J.J., Nutrition and reproduction, Anim. Reprod. Sci. 42 (1996) 25-34.

[69] Schillo K.K., Hall J.B., Hileman S.M., Effects of nutrition and season on the onset of puberty in the beef heifer, J. Anim. Sci. 70 (1992) 3994-4005.

[70] Sejrsen K., Purup S., Influence of prepubertal feeding level on milk yield potential of dairy heifers: a review, J. Anim. Sci. 75 (1997) $828-835$.

[71] Sejrsen K., Relationships between nutrition, puberty and mammary development in cattle, Proc. Nutr. Soc. 53 (1994) 103-111.

[72] Short R.E., Bellows R.A., Staigmiller R.B. Berardinelli J.G., Custer E.E., Physiological mechanisms controlling anestrus and infertility in postpartum beef cattle, J. Anim. Sci. 68 (1990) $799-816$.

[73] Sibbald A.M., Fenn P.D., Kerr W.G., Loudon A.S.I., The influence of birth date on the development of seasonal cycles in red deer hinds (Cervus elaphus), J. Zool. 230 (1993) 593-607.

174] Sinclair K.D., Yildiz S., Quintans G., Broadbent P.J., Annual energy intake and the performance of beef cows differing in body size and milk potential, Anim. Sci. 66 (1998) 634-655. 
[75] Sinclair K.D., Yildiz S., Quintans G., Gebbie F.E., Broadbent P.J., Annual energy intake and the metabolic and reproductive performance of beef cows differing in body size and milk potential, Anim. Sci. 66 (1998) 657-666.

[76] Taylor St. C.S., Turner H.G., Young G.B., Genetic control of equilibrium maintenance efficiency in cattle, Anim. Prod. 33 (1981) 179-194.

[77] Taylor St. C.S., Murray J.I., Effect of feeding level, breed and milking potential on body tissues and organs of mature, non-lactating cows, Anim. Prod. 53 (1991) 27-38.

[78] Troccon J.L., Berge P., Agabriel J., Alimentation des veaux et génisses d'élevage, in: Jarrige R. (Ed.), Alimentation des Bovins Ovins Caprins, Inra, 1988, pp. 201-212.

[79] Vera R.R., Growth and conception in continuously underfed Brahman heifers, Anim. Prod. 53 (1991) 45-50.

[80] Vera R.R., Ramirez C.A., Ayala H., Reproduction in continuously underfed Brahman cows, Anim. Prod. 57 (1993) 193-198.

181] Williams L.M., Hannah L.T., Adam C.L., Bourke D.A., Melatonin receptors in red deer fetuses (Cervus elaphus), J. Reprod. Fertil. 110 (1997) 145-151.

[82] Wright I.A., Russel A.J.F., Hunter E.A., Compensatory growth in cattle grazing different vegetation types, Anim. Prod. 48 (1989) 43-50.

[83] Wright I.A., Russel A.J.F., Changes in the body composition of beef cattle during compensatory growth, Anim. Prod. 52 (1991) 105-113.

[84] Wright I.A., Rhind S.M., Whyte T.K., Smith A.J., Effects of body condition at calving and feeding level after calving on LH profiles and the duration of the post-partum anoestrous period in beef cows, Anim. Prod. 55 (1992) 4146

[85] Yambayamba E.S.K., Price M.A., Effect of compensatory growth on mammary growth and development in beef heifers, Livestock Prod. Sci. 51 (1997) 237-244.

[86] Yan Y., Gordon F.J., Ferris C.P., Agnew R.E., Porter M.G., Patterson D.C., The fasting metabolism of non-pregnant dry dairy cows offered forage diets ad libitum prior to starvation, Proc. Br. Soc. Anim. Prod., 1997, 117 p. 